\title{
H-Y Antigen and Homosexuality in Men
}

\author{
Ray Blanchard* and Philip KLasSEN \\ Department of Psychiatry, University of Toronto and the Clarke Institute of Psychiatry, \\ Toronto, Ontario, Canada
}

(Received on 29 July 1996, Accepted in revised form on 18 November 1996)

\begin{abstract}
In men, sexual orientation correlates with the number of older brothers, each additional older brother increasing the odds of homosexuality by approximately $33 \%$. It is hypothesized that this fraternal birth order effect reflects the progressive immunization of some mothers to Y-linked minor histocompatibility antigens ( $\mathrm{H}-\mathrm{Y}$ antigen) by each succeeding male fetus, and the concomitantly increasing effects of $\mathrm{H}-\mathrm{Y}$ antibodies on the sexual differentiation of the brain in each succeeding male fetus. This hypothesis is consistent with a variety of evidence, including the apparent irrelevance of older sisters to the sexual orientation of later-born males, the probable involvement of $\mathrm{H}-\mathrm{Y}$ antigen in the development of sex-typical traits, and the detrimental effects of immunization of female mice to $\mathrm{H}-\mathrm{Y}$ antigen on the reproductive performance of subsequent male offspring.
\end{abstract}

(C) 1997 Academic Press Limited

\section{Introduction}

There is now substantial evidence that sexual orientation in men is correlated with birth order, later births being associated with an increased likelihood of homosexuality (Slater, 1962; Hare \& Moran, 1979; Blanchard \& Sheridan, 1992; Blanchard \& Zucker, 1994; Zucker \& Blanchard, 1994; Blanchard et al., 1995, 1996; Blanchard \& Bogaert, 1996a, b). This relation has been demonstrated in subjects examined in recent years and subjects examined decades ago, in groups collected in England, The Netherlands, Canada, and the United States, in psychiatric patients and in non-patient volunteers, in subjects examined in adulthood and subjects examined in childhood, and in men who wish they were women as well as men contented with their male role and anatomy. The collective evidence, therefore, suggests that a high birth order is associated with homosexuality in men,

\footnotetext{
*Author to whom correspondence should be addressed at: Head, Clinical Sexology Program, Clarke Institute of Psychiatry, 250 College Street, Toronto, Ontario M5T 1R8, Canada.

E-mail: blanchardr@cs.clarke-inst.on.ca
}

regardless of their other cultural, demographic, or psychological characteristics.

Two recent studies have investigated whether sexual orientation is primarily correlated with a man's number of older brothers or with his number of older siblings regardless of sex (Blanchard \& Bogaert, 1996a, b). Their findings indicate that sexual orientation is primarily correlated with the number of older brothers. In the one study that attempted to quantify this effect, each additional older brother increased the odds of homosexuality by approximately 33\% (Blanchard \& Bogaert, 1996a). Both studies found that a man's number of older sisters does not correlate with his sexual orientation, once his number of older brothers has been taken into account. These results restrict the range of possible theories of the birth order effect to those that can explain not only why older brothers increase the odds of homosexuality in later-born males but also why older sisters neither enhance this effect nor counteract it.

A possible immunologic explanation of the birth order effect - perhaps better called the fraternal birth order effect - was noted by Blanchard \& Bogaert (1996a), but with little accompanying rationale. The present article was therefore written to summarize the

(C) 1997 Academic Press Limited 
various arguments and lines of indirect evidence that support this hypothesis.

\section{The Maternal Immune Hypothesis}

Blanchard \& Bogaert (1996a) proposed that the fraternal birth order effect might involve a maternal immune reaction that is provoked only by male fetuses, and that becomes stronger after each pregnancy with a male fetus. They further theorized that the relevant fetal antigen might be one of the male-specific, Y-linked, minor histocompatibility antigens, often referred to collectively as $\mathrm{H}-\mathrm{Y}$ antigen (e.g., Wolf et al., 1992).

There appear to be at least three distinct male-specific antigenic systems (Müller, 1996). The first is recognized by transplantation assays (or assays that correlate with transplantation such as the cytotoxic $\mathrm{T}$ cell assay), and the second is detected serologically. The gene controlling the expression of transplantation $\mathrm{H}-\mathrm{Y}$ antigen is located, in humans, on the long arm of the $\mathrm{Y}$ chromosome, and that controlling the expression of serological $\mathrm{H}-\mathrm{Y}$ antigen resides on the short arm of the $\mathrm{Y}$ chromosome. The third form of $\mathrm{H}-\mathrm{Y}$ antigen ("soluble $\mathrm{H}-\mathrm{Y}$ ") has been shown to be identical to anti-Müllerian hormone (also called Müllerian-inhibiting substance), the testicular factor responsible for prenatal regression of the Müllerian ducts in male embryos. With the exception of soluble $\mathrm{H}-\mathrm{Y}$, the specific functions of $\mathrm{H}-\mathrm{Y}$ antigen have not been established. One possible clue comes from recent research suggesting that the protein from which one H-Y antigen is derived may be a transcription factor, activating or repressing the expression of other genes (Scott et al., 1995; Wang et al., 1995).

$\mathrm{H}-\mathrm{Y}$ antigen almost certainly has some role or roles in the sexual differentiation of vertebrates (Wachtel, 1983), because it is usually present in the heterogametic and absent in the homogametic sex-in mammals, present in males and absent in femalesand because it has been highly conserved throughout vertebrate evolution (Wachtel et al., 1975; Nakamura et al., 1987). The possible involvement of H-Y antigen in the development of sex-typical traits suggests that fetal exposure to $\mathrm{H}-\mathrm{Y}$ antibodies could affect subsequent sexual behavior in men.

Because $\mathrm{H}-\mathrm{Y}$ antigen is expressed by male fetuses but not by female fetuses, a woman's immune system would be able to "remember" the number of male (but not female) fetuses that she has previously carried and to progressively alter its response to the next fetus according to the current tally of preceding males. Thus, this hypothesis can explain why the odds of homosexuality are increased by each additional older brother, but are not affected in any way by an individual's number of older sisters (Blanchard \& Bogaert, 1996a).

\section{Clinical and Experimental Evidence of Maternal Response to H-Y Antigen}

However well H-Y antigen might fit the requirements of the immune theory, it cannot be relevant unless the immune systems of pregnant females recognize and react to it. Animal research has clearly established that the maternal immune system does respond to fetal H-Y antigen (Silvers, 1968; Smith \& Powell, 1977; Uphoff, 1974; Haughton et al., 1979; Krupen-Brown \& Wachtel, 1979; Shalev, 1980), as evidenced by either immunization or tolerance, depending on the experimental procedure and sometimes on the individual subject.

$\mathrm{H}-\mathrm{Y}$ antigen has been hypothesized as the reason for a variety of empirical evidence that male fetuses are more antigenic to human mothers than are female fetuses and more likely to provoke maternal immune reactions. Epidemiological evidence suggesting greater male antigenicity, including the observation that male fetuses are more likely than female fetuses to initiate maternal $\mathrm{Rh}$ immunization, has previously been reviewed by Gualtieri \& Hicks (1985). Another line of evidence is higher levels of antibodies, presumably of maternal origin, in the sera of male fetuses or their mothers (Johansen et al., 1974; Farber et al., 1981; Avrech et al., 1994). These findings are consistent with in vitro research with mixed motherchild lymphocyte cultures, showing that maternal immune response is greater to stimulating cells from male than from female children (Komlos et al., 1989, 1990). In all of the foregoing reports, direct or indirect effects of $\mathrm{H}-\mathrm{Y}$ antigen were advanced as possible explanations of the observed differences.

\section{The Possibility of Selective Action of H-Y Antibodies}

If maternal $\mathrm{H}-\mathrm{Y}$ antibodies influence future sexual orientation by acting on the fetus, they most likely do so by diverting the sexual differentiation of the fetal brain from the male-typical pathway. This idea is supported by the findings of relevant neuroanatomical studies. One postmortem study has shown that, in homosexual men, a sex-dimorphic interstitial nucleus of the anterior hypothalamus, INAH3, is shifted in size toward the range typical for women (LeVay, 1991); and another postmortem study of the brain has yielded similar results for the anterior commissure (Allen \& Gorski, 1992). 
The fetal brain is potentially accessible to $\mathrm{H}-\mathrm{Y}$ antibodies because the blood-brain barrier is not completely developed during prenatal life. Therefore, the plausibility of the maternal immune hypothesis rests on the answers to two questions: (1) how likely is it that brain tissue would be a target of $\mathrm{H}-\mathrm{Y}$ antibodies; and (2) could H-Y antibodies affect sexual differentiation in the brain without affecting differentiation in other sex-dimorphic organs, in particular, the genitalia?

The first question pertains to the matter of tissue localization. H-Y antigen is expressed on most or all cell types in males, but not to the same extent on all types (Koo, 1981). It appears to be most strongly represented on the surfaces of brain cells (Schachner \& Hämmerling, 1974), epidermal cells (Scheid et al., 1972), and gonadal cells, including sperm cells (Goldberg et al., 1971; Koo \& Goldberg, 1978; Zaborski, 1979).

The presence of $\mathrm{H}-\mathrm{Y}$ antigen on epidermal and sperm cells as well as brain cells does not necessarily contradict the pattern of tissue distribution required by the hypothesis. The vulnerability of sperm cells to $\mathrm{H}-\mathrm{Y}$ antibodies is of uncertain relevance here, because mature sperm are not produced by the fetus. The expression of $\mathrm{H}-\mathrm{Y}$ antigen in epidermal cells is also reconcilable with the notion that $\mathrm{H}-\mathrm{Y}$ antibodies could exert their greatest effect on brain development. It is possible that a critical role of $\mathrm{H}-\mathrm{Y}$ antigen is in the sexual differentiation of the brain, that it performs no important function in epidermal tissue, and that it is relatively abundant in epidermal tissue merely because skin and brain are both ectodermal derivatives. If that is the case, prenatal exposure to $\mathrm{H}-\mathrm{Y}$ antibodies might have little effect on skin development. Thus, data regarding the tissue distribution of $\mathrm{H}-\mathrm{Y}$ antigen are compatible with the notion that $\mathrm{H}-\mathrm{Y}$ antibodies could have a selective effect on brain tissue. It should be noted that there are some contradictory data regarding the expression of $\mathrm{H}-\mathrm{Y}$ antigen by brain cells (Johnson et al., 1981); however, this could be attributed to technical differences in the assays employed, because tests for $\mathrm{H}-\mathrm{Y}$ antigen have proven very difficult (Wachtel, 1983).

The second question was whether $\mathrm{H}-\mathrm{Y}$ antibodies could be present in sufficient quantities to affect the sexual differentiation of the fetal brain, without also affecting the development of the genitalia. In mice, testes can develop in the complete absence of $\mathrm{H}-\mathrm{Y}$ antigen (McLaren et al., 1984). It is therefore plausible that the genitalia could develop normally in human males whose $\mathrm{H}-\mathrm{Y}$ antigen is only partly bound by $\mathrm{H}-\mathrm{Y}$ antibodies.
Even if the maternal immune hypothesis is correct, the actual mechanism by which $\mathrm{H}-\mathrm{Y}$ antibodies affect the sexual differentiation of the brain would remain to be clarified. One possibility is suggested by the previously mentioned evidence that $\mathrm{H}-\mathrm{Y}$ antigen might be a transcription factor (Scott et al., 1995; Wang et al., 1995). In that case, $\mathrm{H}-\mathrm{Y}$ antibodies might decrease the ability of $\mathrm{H}-\mathrm{Y}$ antigen to perform its usual function. Another possibility is that $\mathrm{H}-\mathrm{Y}$ antibodies interfere with the customary organizational role of some sex hormone, perhaps by producing an exaggerated version of that hormone's usual effect, with paradoxical consequences. Evidence that relatively specific immunohormonal interaction might occur comes from a study by Flaherty et al. (1979). These authors found that cell surface changes involving $\mathrm{H}-\mathrm{Y}$ and components of the major histocompatibility complex are induced in the presence of H-Y antibody (Flaherty et al., 1979). This may be physiologically relevant because testosterone but not estradiol induces the same changes. Any changes involving the major histocompatibility complex at the cell surface would have profound effects on embryonic development.

\section{Sex Ratios of Offspring of Immunized Mothers and Sibling Sex Ratios of Homosexual Men}

Other data relevant to the maternal immune hypothesis include the finding that the ratio of males to females in the sibships of homosexual men matches population norms or significantly exceeds them. This finding is congruent with the known effects of maternal immunization to $\mathrm{H}-\mathrm{Y}$ on the sex ratio of live-born offspring.

In white populations, the ratio of male live births to female live births is close to 106:100 (James, 1987; Chahnazarian, 1988). The ratio of brothers to sisters reported by any group of men drawn at random from the general population should therefore approach 106 (brothers per 100 sisters). Studies of homosexual males recruited without regard to psychological masculinity-femininity have found sibling sex ratios ranging from 98 to 126 (Jensch, 1941; Kallmann, 1952; Slater, 1958; Lang, 1960; Blanchard \& Zucker, 1994; Zucker \& Blanchard, 1994; Blanchard \& Bogaert, 1996a, b). Studies of extremely feminine homosexual or prehomosexual males have produced markedly elevated ratios ranging from 131 to 157 (Jensch, 1941; Blanchard \& Sheridan, 1992; Blanchard et al., 1995, 1996; Zucker et al., in press). It is unclear at this point whether the pattern of highest sibling sex ratios for the most feminine homosexuals is meaningful or fortuitous. 
The finding that the sibling sex ratio of homosexual men matches or exceeds the expected value is consistent with two lines of evidence suggesting that maternal immune reactions to $\mathrm{H}-\mathrm{Y}$ antigen either have no effect on the sex ratio of live-born offspring or else increase the proportion of males. Laboratory studies have shown that immunization of female mice to $\mathrm{H}-\mathrm{Y}$ antigen does not affect the male:female sex ratio of their offspring (McLaren, 1962; Lappé \& Schalk, 1971; Shalev et al., 1980; Hings \& Billingham, 1984) and that immunization plus removal of the spleen, an organ that can dampen immune responses to H-Y antigen (Streilein \& Wiesner, 1977), actually increases the sex ratio (Lappé \& Schalk, 1971; Shalev et al., 1980; Hings \& Billingham, 1984).

The second line of evidence is research on human births relevant to the hypothesis that maternal immune reactions to $\mathrm{H}-\mathrm{Y}$ antigen may affect the probability of implantation of male zygotes, and that this effect will be seen most clearly when mother and zygote are relatively compatible regarding autosomal antigens (Kirby et al., 1967). This research similarly suggests that immune reactions to $\mathrm{H}-\mathrm{Y}$ either have no effect on the sex ratio at birth (Kilpatrick, 1987; Clayton et al., 1988) or else increase the proportion of males delivered (Ober et al., 1985; Radvany et al., 1987). Thus, the elevated sex ratios sometimes observed in the sibships of homosexual men could also be explained as the result of maternal immunization to $\mathrm{H}-\mathrm{Y}$ antigen.

\section{Birth Order in Homosexual Females}

The maternal immune hypothesis applies only to male homosexuality, but the epidemiology of female homosexuality also bears on it. The hypothesis does not predict a high mean birth order for homosexual females, because female fetuses do not produce $\mathrm{H}-\mathrm{Y}$ antigen and they would not be targets of H-Y antibodies. Therefore, a finding that homosexual females also have a high mean birth order would cast doubt on the immune hypothesis, suggesting instead some psychosocial mechanism that operates in the same way for males and females. In general, the published studies of birth order in homosexual females have been carried out on smaller samples than the studies of males, and they are otherwise methodologically less satisfactory. What data exist, however, show no evidence of any consistent trend toward later births for homosexual women. Saghir \& Robins (1973) found a tendency for homosexual women to be born early in their sibships, Slater (1962) found a tendency for them to be born late, and Blanchard \& Sheridan (1992) and Hare \& Moran
(1979) found neither. Thus, the epidemiology of female homosexuality is consistent with the hypothesis that the high birth order of homosexual males reflects a maternal immune reaction that is provoked only by males and affects only males.

\section{Animal Research}

Finally, the only relevant animal study known to us supports the notion that exposure to $\mathrm{H}-\mathrm{Y}$ antibodies in utero could affect subsequent sexual behavior in males. Singh \& Verma (1987) immunized two groups of female mice to $\mathrm{H}-\mathrm{Y}$ antigen by injecting them intraperitoneally with male spleen cells. One group was from an inbred and one from an outbred strain. Two groups of female control mice from the same strains were injected with saline solution. All four groups were then allowed to mate and give birth to their litters. When the male pups from these litters had grown to maturity, the investigators studied their reproductive performance. Only $10 \%$ of the males born to the immunized females "performed successful mating" (p. 151), compared with $100 \%$ of the males born to the control females; these percentages were the same for the inbred and the outbred animals. Singh \& Verma did not, unfortunately, give any further description of the "very poor reproductive performance" (p. 151) of the sons of immunized mothers; this could represent a lack of interest in estrous females, or incompetence at mounting in the correct position, or a failure to thrust a sufficient number of times to ejaculate. The behavioral deficit appears to have been somewhat independent of gonadal abnormalities; the inbred males were described as nearly sterile but the outbred males were not.

\section{Multiple Determinants of Sexual Orientation}

The foregoing argumentation is not meant to imply that maternal immune responses are the only cause of homosexuality in men. There are almost certainly multiple influences on sexual orientation, including genetic inheritance (Hamer et al., 1993; Hu et al., 1995) and possibly endocrinologic events in utero. If the maternal immune hypothesis is true, H-Y antibodies would simply be one more factor.

Preparation of this article was supported in part by grant 410-95-0003 from the Social Sciences and Humanities Research Council of Canada to Ray Blanchard. The authors thank Drs Stephen S. Wachtel and Robert H. Lustig for their helpful comments on earlier drafts of the article. 


\section{REFERENCES}

Allen, L. S. \& Gorski, R. A. (1992). Sexual orientation and the size of the anterior commissure in the human brain. Proc. Natn. Acad. Sci. U.S.A. 89, 7199-7202.

Avrech, O. M., Samra, Z., Lazarovich, Z., Caspi, E., Jacobovich, A. \& Sompolinsky, D. (1994) Efficacy of the placental barrier for immunoglobulins: Correlations between maternal, paternal and fetal immunoglobulin levels. Int. Archs Allergy Immun. 103, $160-165$.

Blanchard, R. \& Bogaert, A. F. (1996a). Homosexuality in men and number of older brothers. Am. J. Psychiat. 153, 27-31.

Blanchard, R. \& Bogaert, A. F. (1996b). Biodemographic comparisons of homosexual and heterosexual men in the Kinsey interview data. Arch. Sex. Behav. 25. 551-579

Blanchard, R. \& Sheridan, P. M. (1992). Sibship size, sibling sex ratio, birth order, and parental age in homosexual and nonhomosexual gender dysphorics. J. Nerv. Ment. Dis. 180, 40- 47.

Blanchard, R. \& Zucker, K. J. (1994). Reanalysis of Bell, Weinberg, and Hammersmith's data on birth order, sibling sex ratio, and parental age in homosexual men. Am. J. Psychiat. 151, 1375-1376.

Blanchard, R., Zucker, K. J., Bradley, S. J. \& Hume, C. S. (1995). Birth order and sibling sex ratio in homosexual male adolescents and probably prehomosexual feminine boys. Dev. Psychol. 31, 22-30.

Blanchard, R., Zucker, K. J., Cohen-Kettenis, P. T., Gooren, L. J. G. \& BAILEY, J. M. (1996). Birth order and sibling sex ratio in two samples of Dutch gender-dysphoric homosexual males. Arch. Sex. Behav. 25, 495-514.

Chahnazarian, A. (1988). Determinants of the sex ratio at birth: Review of recent literature. Social Biol. 35, 214-235.

Clayton, J., Cambon-Thomsen, A., Sevin, A., Thomsen, M. \& OHAYon, E. (1988). No evidence for sex ratio distortion in relation with feto-maternal HLA-DR compatibility. Tissue Antigens 32, 286-290.

Farber, C.-M., Cambiaso, C. L. \& Masson, P. L. (1981). Immune complexes in cord serum: influence of sex, gestational age, and $\mathrm{Rh}^{-}$blood group - possible predictive value of high levels for early postnatal infections. Clin. \& Exp. Immunol. 44, 426-432.

Flaherty, L., Zimmerman, D. \& Wachtel, S. S. (1979). H-Y antigen: Cell surface mapping and testosterone-induced supramolecular repatterning. J. Exp. Med. 150, 1020-1027.

Goldberg, E. H., Boyse, E. A., Bennett, D., Scheid, M. \& Carswell, E. A. (1971). Serological demonstration of H-Y (male) antigen on mouse sperm. Nature 232, 478-480.

GUALTIERI, T. \& Hicks, R. E. (1985). An immunoreactive theory of selective male affliction. Behav. \& Brain Sci. 8, 427-441.

Hamer, D. H., Hu, S., Magnuson, V. L., Hu, N. \& Pattatucci, A. M. L. (1993). A linkage between DNA markers on the $\mathrm{X}$-chromosome and male sexual orientation. Science $\mathbf{2 6 1}$, 321-327.

Hare, E. H. \& Moran, P. A. P. (1979). Parental age and birth order in homosexual patients: A replication of Slater's study. $\mathrm{Br} . \mathrm{J}$. Psychiat. 134, 178-182.

Haughton, G., Daly, J. A. \& Wikstrand, C. J. (1979). An investigation of allograft tolerance: Discordant reactivity to murine $\mathrm{H}-\mathrm{Y}$-incompatible lymphoid cell (PEC) and skin grafts. Transplantation 27, 203-207.

Hings, I. \& Billingham, R. E. (1984). H-Y antigen and immunity: a means for controlling the secondary sex ratio? J. Reprod. Immunol. 6, 345-352.

Hu, S., Pattatucci, A. M. L., Patterson, C., Li, L., Fulker, D. W., Cherny, S. S., Kruglyak, L. \& Hamer, D. H. (1995). Linkage between sexual orientation and chromosome Xq28 in males but not in females. Nature Genetics 11, 248-256.

JAmES, W. H. (1987). The human sex ratio. Part 1: A review of the literature. Hum. Biol. 59, 721-752.

JeNSCH, K. (1941). Weiterer Beitrag zur Genealogie der Homosexualität. Arch. Psychiat. Nervkrankh. 112, 679-696.

Johansen, K., Festenstein, H. \& Burke, J. (1974). Possible relationships between maternal HL-A antibody formation and fetal sex: Evidence for a sex-linked histocompatibility system in man. J. Obstet. Gynaec. Br. Commonw. 81, 781-785.

Johnson, L. L., Bailey, D. W. \& Mobraaten, L. E. (1981). Genetics of histocompatibility in mice. IV. Detection of certain minor (non-H-2) $\mathrm{H}$ antigens in selected organs by the popliteal node test. Immunogenetics 14, 63-71.

Kallmann, F. J. (1952). Twin and sibship study of overt male homosexuality. Am. J. Hum. Genet. 4, 136-146.

KilPATRICK, D. C. (1987). Feto-maternal HLA-DR compatibility and sex ratio. Tissue Antigens 30, 235-237.

Kirby, D. R. S., McWhirter, K. G., Teitelbaum, M. S. \& Darlington, C. D. (1967). A possible immunological influence on sex ratio. Lancet ii, 139-140.

Komlos, L., Sirota, L., Notman, J., Dulitzky, F., Hart, J., Goldman, J. \& Halbrecht, I. (1989). Role of the newborn's sex in mixed maternal-newborn lymphocyte culture reactivity. Gynecol. Obstet. Invest. 27, 62-69.

Komlos, L., Vardimon, D., Notmann, J., Zamir, R., Klein, T., LiVni, E., et al. (1990). Role of children's sex in mixed mother-child lymphocyte culture reactivity. American Journal of Reproductive Immunology 22, 4-8.

Koo, G. C. (1981). Serology of H-Y antigen. Hum. Genet. 58, 18-20.

Koo, G. C. \& Goldberg, C. L. (1978). A simplified technique for H-Y typing. J. Immunol. Methods 23, 197-201.

Krupen-Brown, K. \& Wachtel, S. S. (1979). Cytotoxic and agglutinating $\mathrm{H}-\mathrm{Y}$ antibodies in multiparous female mice. Transplantation 27, 406-409.

LANG, T. (1960). Die Homosexualität als genetisches Problem. Acta Genet. Med. Gemell. 9, 370-381.

LAPPÉ, M. \& SCHALK, J. (1971). Necessity of the spleen for balanced secondary sex ratios following maternal immunization with male antigen. Transplantation 11, 491-495.

LEVAY, S. (1991). A difference in hypothalamic structure between heterosexual and homosexual men. Science 253, 1034-1037.

MCLaren, A. (1962). Does maternal immunity to male antigen affect the sex ratio of the young? Nature 195, 1323-1324.

Mclaren, A., Simpson, E., Tomonari, K., Chandler, P. \& Hogg, H. (1984). Male sexual differentiation in mice lacking $\mathrm{H}-\mathrm{Y}$ antigen. Nature 312, 552-555.

Müller, U. (1996). H-Y antigens. Hum. Genet. 97, 701-704.

Nakamura, D., Wachtel, S. S., LANCE, V. \& BeÇAK, W. (1987). On the evolution of sex determination. Proc. R. Soc. Lond. 232, 159-180.

Ober, C., Simpson, J. L. \& Radvany, R. (1985). Increased male-to-female sex ratio among HLA-DR compatible pregnancies. Lancet i, 761.

Radvany, R. M., Vaisrub, N., Ober, C., Patel, K. M. \& Hecht, F. (1987). The human sex ratio: increase in first-born males to parents with shared HLA-DR antigens. Tissue Antigens 29, 34-42.

SAGHir, M. T. \& Robins, E. (1973). Male and Female Homosexuality: A Comprehensive Investigation. Baltimore: Williams \& Wilkins.

SCHACHNER, M. \& HÄMmERLING, U. (1974). The postnatal development of antigens on mouse brain cell surfaces. Brain Res. 73, 362-371.

Scheid, M., Boyse, E. A., Carswell, E. A. \& Old, L. J. (1972). Serologically demonstrable alloantigens of mouse epidermal cells. J. Exp. Med. 135, 938-955.

Scott, D. M., Ehrmann, I. E., Ellis, P. S., Bishop, C. E., Agulnik, A. I., Simpson, E. \& Mitchell, M. J. (1995). Identification of a mouse male-specific transplantation antigen, H-Y. Nature 376, 695-698

Shalev, A. (1980). Pregnancy-induced H-Y antibodies and their transmission to the foetus in rats. Immunology 39, 285-289.

Shalev, A., Nelson, N. A. \& Hamerton, J. L. (1980). Evidence for the role of the maternal immune system in balancing the sex ratio in mice. J. Reprod. Immunol. 2, 187-198.

SILVERS, W. K. (1968). Studies on the induction of tolerance of the 
H-Y antigen in mice with neonatal skin grafts. J. Exp. Med. 128, $69-83$.

Singh, J. \& Verma, I. C. (1987). Influence of major histo(in)compatibility complex on reproduction. Am. J. Reprod. Immunol. Microbiol. 15, 150-152.

Slater, E. (1958). The sibs and children of homosexuals. In: Symposium on Nuclear Sex (Smith, D. R. \& Davidson, W. M., eds) pp. 79-83. London: Heinemann Medical Books.

Slater, E. (1962). Birth order and maternal age of homosexuals. Lancet i, 69-71.

Smith, R. N. \& Powell, A. E. (1977). The adoptive transfer of pregnancy-induced unresponsiveness to male skin grafts with thymus-dependent cells. J. Exp. Med. 146, 899-904.

Streilein, J. W. \& WieSNER, J. (1977). Influence of splenectomy on first set rejection reactions of $\mathrm{C} 57 \mathrm{BL} / 6$ females to male skin isografts. J. Exp. Med. 146, 809-816.

UphOFF, D. E. (1974). Maternal influence on responsiveness of multiparous mice to the antigenic characteristics of their male progeny. J. Natn. Cancer Inst. 52, 1843-1847.
Wachtel, S. S. (1983). H-Y Antigen and the Biology of Sex Determination. New York: Grune \& Stratton.

Wachtel, S. S., Koo, G. C. \& Boyse, E. A. (1975). Evolutionary conservation of H-Y ('male') antigen. Nature 254, 270-272.

Wang, W., Meadows, L. R., Den HaAn, J. M. M., Sherman, N. E., Chen, Y., Blokland, E., et al. (1995). Human H-Y: A male-specific histocompatibility antigen derived from the SMCY protein. Science 269, 1588-1590.

WOLF, U., SCHEMPP, W. \& SCHERER, G. (1992). Molecular biology of the human $\mathrm{Y}$ chromosome. Rev. Physiol. Biochem. Pharmacol. 121, 147-213.

ZABORSKI, P. (1979). Detection of H-Y antigen on mouse sperm by the use of Staphylococcus aureus. Transplantation 27, 348-350.

ZuCKeR, K. J. \& BlANCHARD, R. (1994). Reanalysis of Bieber et al.'s 1962 data on sibling sex ratio and birth order in male homosexuals. J. Nerv. Ment. Dis. 182, 528-530.

Zucker, K. J., Green, R., Coates, S., Zuger, B., Cohen-Kettenis, P. T., ZecCa, G. M. et al. Sibling sex ratio of boys with gender identity disorder. J. Child Psychol. Psychiat. (in press) 